\title{
Evaluasi Klon-Klon Tebu Potensial di Lahan Kering
}

\section{Evaluation of Potential Sugarcane Clones in the Upland}

\author{
Djumali*, Bambang Heliyanto, dan Ahmad Dhiaul Khuluq \\ Balai Penelitian Tanaman Pemanis dan Serat \\ J1. Raya Karangploso Kotak Pos 199 Malang 65152, Indonesia
}

Diterima 18 April 2018/Disetujui 6 November 2018

\begin{abstract}
The candidates for new superior varieties are expected to be able to increase the sugar yield in the upland area. Germplasm evaluation has indicated some clones had potentially high sugar yield in upland area. The study was conducted at Asembagus Experimental Station, Situbondo Regency, East Java, from December 2016 to November 2017. The study aimed to obtain sugarcane clones with higher sugar yield than existing varieties on upland area. Twelve potential sugarcane clones (17, 87, 90, 104, 212, 351, 354, 451, 452, PBG 2, 386 SOF 1118, and 400 SOF 1132) and 2 check varieties (PS 881 and Cenning) were arranged in a randomized block design with three replicates. The results showed that the sugarcane production of 104, 212, and PBG 2 clones (97.42-98.26 ton ha $^{-1}$ ) were not different from productivity of Cenning (105.42 ton $\left.\mathrm{ha}^{-1}\right)$ but they were higher than that of PS 881 (75.68 ton ha $\mathrm{h}^{-1}$ ). The sugar content of 104 and PBG 2 clones (9.43-9.46\%) was higher than Cenning (6.94\%) but lower than PS 881 (11.66\%). The sugar yields (9.16-9.24 ton ha-1) of 104 and PBG 2 clones were higher than Cenning (7.47 ton ha $\left.\mathrm{h}^{-1}\right)$ but they were not different from PS 881 (8.84 ton ha $\left.\mathrm{h}^{-1}\right)$.
\end{abstract}

Keywords: Genetic, productivity, Saccharum officinarum L., sugar content, sugar yield

\section{ABSTRAK}

Calon varietas unggul baru diharapkan dapat meningkatkan hasil hablur tebu di lahan kering. Hasil karakterisasi plasma nutfah menunjukkan bahwa beberapa klon mempunyai hasil yang tinggi di lahan kering. Penelitian dilakukan di Kebun Percobaan Asembagus, Kabupaten Situbondo, Jawa Timur mulai Desember 2016 sampai November 2017. Penelitian bertujuan untuk memperoleh klon-klon tebu yang mempunyai hasil hablur lebih tinggi dibanding varietas unggul di lahan kering. Dua belas klon tebu potensial (17, 87, 90, 104, 212, 351, 354, 451, 452, PBG 2, 386 SOF 1118, dan 400 SOF 1132) dan 2 varietas pembanding (PS 881 dan Cenning) disusun dalam Rancangan Acak Kelompok dan diulang 3 kali. Hasil penelitian menunjukkan bahwa klon 104, 202, dan PBG 2 menghasilkan produktivitas tebu (97.42-98.26 ton ha') tidak berbeda dengan Cenning (105.42 ton ha ${ }^{-1}$ ) tetapi lebih tinggi dibanding PS 881 (75.68 ton ha ${ }^{-1}$ ). Potensi rendemen (9.43-9.46\%) klon 104 dan PBG 2 lebih besar dibanding Cenning (6.94\%) tetapi lebih kecil dibanding PS 881 (11.66\%), sedangkan hasil hablur (9.16-9.24 ton ha $\mathrm{h}^{-1}$ ) lebih tinggi dibanding Cenning (7.47 ton ha $\left.{ }^{-1}\right)$ tetapi tidak berbeda dengan PS 881 (8.84 ton $\left.\mathrm{ha}^{-1}\right)$.

Kata kunci: Genetik, hasil hablur, produktivitas, rendemen, Saccharum officinarum L.

\section{PENDAHULUAN}

Produksi gula nasional pada tahun 2014-2016 baru mencapai 2.43 juta ton per tahun (Ditjenbun, 2017). Kebutuhan gula nasional pada tahun 2014-2016 sebesar 5.68 juta ton per tahun sehingga diperlukan impor gula sebesar 3.25 juta ton per tahun (BPS, 2016). Total kebutuhan gula tersebut terdiri atas kebutuhan gula konsumsi sebesar 2.74 juta ton dan sisanya berupa gula rafinasi. Luas areal tanaman tebu tahun 2017 sebesar 453 ribu hektar

\footnotetext{
* Penulis untuk korespondensi. e-mail: djumali_62@yahoo.com
}

(Ditjenbun, 2017), sehingga untuk memenuhi kebutuhan gula konsumsi diperlukan hasil hablur mencapai 6.05 ton ha $^{-1}$. Kebutuhan gula nasional tercapai apabila hasil hablur mencapai 12.53 ton $\mathrm{ha}^{-1}$. Hasil hablur selama tahun 20142016 hanya sebesar 5.34 ton ha ${ }^{-1}$ dengan rendemen sebesar 7.82\% (Ditjenbun, 2017) sehingga perlu ditingkatkan untuk memenuhi kebutuhan gula konsumsi maupun kebutuhan gula nasional.

Delapan puluh persen luas areal pertanaman tebu di Indonesia berupa lahan kering dan sisanya berupa lahan sawah (Ditjenbun, 2017). Salah satu upaya yang dapat dilakukan untuk meningkatkan hasil hablur adalah memperoleh varietas unggul baru yang sesuai dengan 
kondisi lahan kering. Varietas unggul baru dapat diperoleh melalui evaluasi potensi klon dalam plasma nutfah. Klonklon yang terkumpul dalam plasma nutfah tebu berasal dari hasil eksplorasi, hasil persilangan, akuisisi dan pertukaran plasma nutfah sehingga peluang untuk memperoleh varietas unggul baru sangat besar.

Hasil karakterisasi dan evaluasi plasma nutfah tebu memperlihatkan adanya klon-klon yang mempunyai hasil hablur tinggi (Heliyanto et al., 2016). Klon-klon tersebut perlu dicoba dikembangkan di lahan kering untuk diketahui potensi hasil hablurnya. Oleh karena itu dilakukan penelitian yang bertujuan untuk memperoleh klon-klon tebu yang mempunyai hasil hablur lebih tinggi dibanding varietas unggul di lahan kering.

\section{BAHAN DAN METODE}

Penelitian dilakukan di Kebun Percobaan Asembagus, Kabupaten Situbondo, Jawa Timur mulai Desember 2016 sampai dengan November 2017. Lahan penelitian berjenis tanah Entisol dengan sifat fisik dan kimia tanah tertera pada Tabel 1 dan curah hujan selama penelitian berlangsung tertera pada Gambar 1. Bahan yang digunakan meliputi benih berbentuk bagal dua mata dari 12 klon tebu $(17,87$, 90, 104, 212, 351, 354, 451, 452, PBG 2, 386 SOF 1118, dan 400 SOF 1132) dan 2 varietas pembanding (PS 881 dan Cenning), pupuk anorganik (Phonska dan ZA), pupuk kandang dari kotoran sapi, pestisida, dan bahan pembantu lainnya. PS 881 dan Cenning merupakan varietas unggul

Tabel 1. Sifat fisik dan kimia tanah percobaan di Kebun Percobaan Asembagus, Situbondo

\begin{tabular}{lrc}
\hline Sifat tanah & Nilai & Kategori \\
\hline $\mathrm{pH} \mathrm{1:1} \mathrm{H}_{2} \mathrm{O}$ & 7.00 & Netral \\
$\mathrm{pH} \mathrm{KCl} \mathrm{1} \mathrm{N}$ & 6.80 & \\
C-Organik (\%) & 0.56 & Sangat rendah \\
$\mathrm{N}$-total (\%) & 0.06 & Sangat rendah \\
$\mathrm{C} / \mathrm{N}$ & 9.30 & Rendah \\
$\mathrm{P}$ Olsen $\left(\mathrm{mg} \mathrm{kg}^{-1}\right)$ & 51.38 & Sangat tinggi \\
$\mathrm{K}\left(\mathrm{NH} 4 \mathrm{OAC} 1 \mathrm{~N} \mathrm{pH:7)(me} 100 \mathrm{~g}^{-1}\right)$ & 1.42 & Sangat tinggi \\
$\mathrm{Na}\left(\mathrm{NH} 4 \mathrm{OAC} 1 \mathrm{~N} \mathrm{pH:7)(me} 100 \mathrm{~g}^{-1}\right)$ & 1.09 & Sangat tinggi \\
$\mathrm{Ca}\left(\mathrm{NH} 4 \mathrm{OAC} 1 \mathrm{~N} \mathrm{pH:7)(me} 100 \mathrm{~g}^{-1}\right)$ & 11.58 & Tinggi \\
$\mathrm{Mg}\left(\mathrm{NH} 4 \mathrm{OAC} 1 \mathrm{~N} \mathrm{pH:7)(me} 100 \mathrm{~g}^{-1}\right)$ & 1.81 & Sedang \\
$\mathrm{KTK}\left(\mathrm{me} 100 \mathrm{~g}^{-1}\right)$ & 15.87 & Rendah \\
Jumlah basa & 15.90 & \\
Kejenuhan Basa (\%) & 100.00 & Sangat tinggi \\
Pasir (\%) & 81.00 & \\
Debu (\%) & 19.00 & Pasir berlempung \\
Liat $(\%)$ & 0.00 & \\
\hline
\end{tabular}

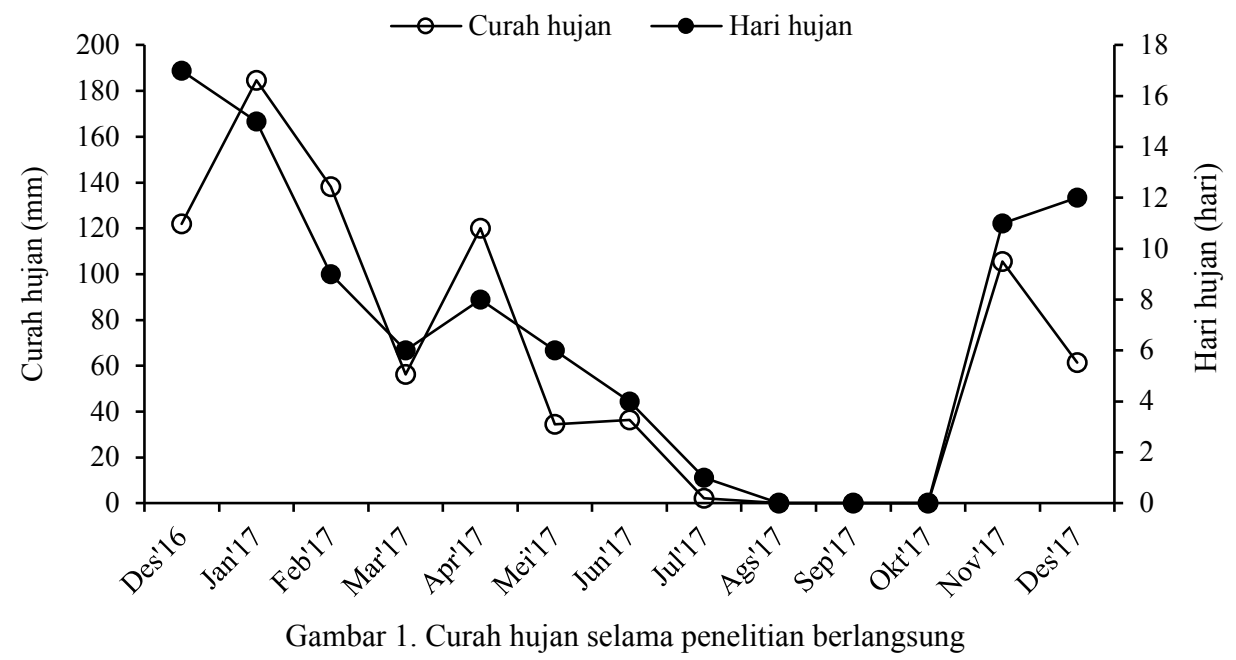


yang banyak digunakan dalam pengembangan tebu di lahan kering. Adapun alat yang digunakan meliputi jangka sorong, refraktometer, polarimeter, Chlorophyll Content Meter tipe CCM-200 plus, Chlorophyll Fluorometer tipe OS-30p+, meteran, dan alat pembantu lainnya.

Klon-klon unggul hasil evaluasi dari koleksi plasma nutfah dan varietas pembanding disusun dalam rancangan acak kelompok dengan tiga ulangan. Setiap klon/varietas ditanam dalam 5 juring dengan panjang juring $5 \mathrm{~m}$ dan jarak pusat ke pusat (PKP) selebar $130 \mathrm{~cm}$. Dengan demikian faktor juring (panjang juringan per hektar) sebesar 6080 m. Sebelum tanam, juringan diberi pupuk kandang sapi sebanyak 10 ton $\mathrm{ha}^{-1}$. Kepadatan populasi tanaman yang digunakan adalah 10 bagal per juringan.

Pemeliharaan tanaman meliputi penyulaman, pemupukan, pembumbunan, pengairan, dan pengendalian hama penyakit. Penyulaman dilakukan 2-3 minggu setelah tanam dengan menaman benih yang tersedia sampai populasi tanaman seperti semula. Pemupukan anorganik (Phonska dan ZA) dilakukan dua kali yakni pada umur 1 dan 3 bulan setelah tanam. Pemupukan dilakukan secara larikan dengan jarak larikan sekitar $10 \mathrm{~cm}$ dari pangkal batang. Potensi klon-klon unggul tidak dapat diperoleh apabila kondisi ketersediaan hara dan air menjadi faktor pembatas bagi pertumbuhan dan produksi tanaman. Keterbatasan ketersediaan hara dalam tanah dapat diatasi dengan pemberian pupuk anorganik. Dosis pupuk yang diberikan 1.25 kali dosis pupuk rekomendasi (750 kg Phonska $+625 \mathrm{~kg}$ ZA per hektar), sesuai rekomendasi Pabrik Gula Asembagus. Pupuk Phonska diberikan pada saat pemupukan I dan pupuk ZA pada saat pemupukan II. Pembumbunan dilakukan 2 kali dengan cara menarik tanahtanah di sekitar juringan ke atas juringan. Pembumbunan I dan II dilakukan setelah pemupukan I dan II. Pengairan dilakukan sebanyak 3 kali selama bulan Juli-Agustus.

Pengamatan khlorofil daun dan fluoresensi khlorofil dilakukan pada fase pertumbuhan batang (umur 6 bulan setelah tanam). Khlorofil daun diukur dengan alat Chlorophyll Content Meter pada daun-daun atas dengan prosedur sesuai dengan petunjuk penggunaan alat (Anonymous, 2012a). Fluoresensi khlorofil diukur dengan alat Chlorophyll Fluorometer pada daun-daun atas yang telah membuka sempurna dengan prosedur sesuai dengan petunjuk penggunaan alat (Anonymous, 2012b). Pengamatan fluoresensi khlorofil menghasilkan data hasil kuantum maksimal dari fotokimia primer (Fv/Fm) dalam fotosistem II.

Pengamatan jumlah batang per $\mathrm{m}$ juring dilakukan menjelang panen dengan cara menghitung seluruh tanaman yang berada pada juring 2, 3, dan 4 (JBT). Tanaman yang dihitung hanya yang berpanjang batang $>1$ meter dan berdiameter $>2.0 \mathrm{~cm}$. Jumlah batang per $\mathrm{m}$ juring (JB) dihitung dengan rumus : JB $=\mathrm{JBT} /(3 \times 5)$, dimana angka 3 menunjukkan jumlah juring yang diamati dan angka 5 menunjukkan panjang juring.

Pengamatan jumlah ruas, panjang ruas, panjang batang, diameter batang, diameter batang, dan bobot batang dilakukan pada saat menjelang panen. Contoh tanaman diambil dari juringan 2, 3, dan 4 masing-masing sebanyak 2 rumpun. Contoh tanaman dipanen dan dihitung jumlah batang contoh. Setiap contoh tanaman dihitung jumlah ruas dan panjang setiap ruas batang. Panjang batang dihitung dari penjumlahan setiap panjang ruas batang pada setiap batang. Diameter batang diukur pada bagian tengah batang setiap tanaman contoh. Bobot batang diukur dengan menimbang seluruh batang contoh tanaman per perlakuan.

Pengamatan potensi rendemen dilakukan menjelang panen dengan mengukur faktor perah, brix dan pol. Contoh tanaman sebanyak 10 batang dari juringan 3 ditimbang bobot batangnya dan diperas untuk diambil niranya. Faktor perah (FP) dihitung dengan rumus : FP = bobot nira / bobot batang

Pengamatan nilai brix dilakukan terhadap nira dengan alat hand refraktometer, sedangkan pengamatan pol dilakukan dengan alat polarimeter. Nilai nira (NN) dihitung dengan rumus: $\mathrm{NN}=$ Pol- $(0.4 \mathrm{x}$ (Brix-Pol) $)$. Potensi rendemen $(\mathrm{PR})$ dihitung dengan rumus: $\mathrm{PR}(\%)=\mathrm{FP} \times \mathrm{NN}$

Pengamatan produktivitas dilakukan saat panen dengan menimbang seluruh batang terpanen (BT) pada juringan 2, 3, dan 4 (total sepanjang $15 \mathrm{~m}$ ). Produktivitas per ha dihitung dengan rumus :

Produktivitas $\left(\right.$ ton $\left.\left.\mathrm{ha}^{-1}\right)=6,080 \mathrm{x}(\mathrm{BT} / 15)\right) / 1,000$.

Hablur dihitung dengan mengalikan antara potensi rendemen dengan produktivitas. Data yang diperoleh dianalisis ragam dan dilanjutkan dengan uji jarak ganda Duncan (DMRT) taraf 5\%. Analisis regresi linier berganda (Stepwise analysis) antarpeubah dilakukan untuk mengetahui pengaruh gabungan antara peubah terhadap peubah lainnya. Nilai koefisien korelasi (r) digunakan sebagai besaran nilai pengaruh.

\section{HASIL DAN PEMBAHASAN}

Kandungan khlorofil relatif dalam daun dan hasil kuantum maksimal dari fotokimia primer dalam fotosistem II (Fv/Fm) berbeda antar klon-klon tebu yang digunakan (Tabel 2). Dua klon (386 SOF 1118 dan 104) berkandungan khlorofil relatif lebih besar, 3 klon $(17,87$, dan 212) tidak berbeda dan 7 klon lainnya lebih rendah dibanding varietas pembanding (Cenning dan PS 881). Klon-klon yang diuji ditumbuhkan dalam lingkungan tumbuh yang homogen sehingga perbedaan kandungan khlorofil daun dipengaruhi oleh genetik tanaman. Streck et al. (2010) menyebutkan kandungan khlorofil dalam daun dipengaruhi oleh genetik tanaman, kondisi lingkungan tumbuh, dan interaksi dari keduanya. Demikian pula Zhao et al. (2015) menyebutkan kandungan khlorofil daun hanya dipengaruhi oleh genetik tanaman bila kondisi lingkungan tumbuhnya homogen. Khlorofil merupakan aparatus pemanen energi cahaya yang diperlukan oleh tanaman tebu untuk proses fotosintesis. Kandungan khlorofil daun berpengaruh positif dengan laju fotosintesis (Zhao et al., 2015).

Klon 386 SOF 1118 menghasilkan Fv/Fm yang lebih besar dan 11 klon lainnya tidak berbeda dengan varietas 
Cenning (Tabel 2). Pembandingan dengan PS 881 diperoleh 2 klon (104 dan 386 SOF 1118) menghasilkan Fv/Fm yang lebih besar dan 10 klon lainnya yang tidak berbeda. Energi cahaya yang diserap khlorofil digunakan untuk proses fotokimia, dihamburkan sebagai panas (disipasi panas) dan dipancarkan kembali sebagai fluoresensi. Ketiga proses tersebut saling bersaing sehingga hasil fluoresensi mengandung informasi tentang efisiensi dua proses lainnya (Stirbert et al., 2014). Fv/Fm merupakan salah satu peubah fluoresensi yang berkaitan erat dengan fotosintesis. Analisis regresi nilai Fv/Fm terhadap kandungan khlorofil relatif daun diperoleh nilai pengaruh sebesar $88.3 \%$. Hasil tersebut memberi arti bahwa $88.3 \%$ nilai $\mathrm{Fv} / \mathrm{Fm}$ ditentukan oleh kandungan khlorofil, sedangkan sisanya ditentukan oleh faktor lain. Klon/varietas yang mempunyai kandungan khlorofil yang tinggi akan menghasilkan nilai Fv/Fm yang tinggi pula. Hasil penelitian Zivcak et al. (2008) memperlihatkan perbedaan nilai $\mathrm{Fv} / \mathrm{Fm}$ disebabkan oleh perbedaan genetik tanaman.

Jumlah ruas, panjang ruas, panjang batang dan diameter batang tebu berbeda antar klon yang digunakan (Tabel 3). Klon 90 berjumlah ruas batang lebih sedikit, 3 klon (104, 354, dan 451) lebih banyak, dan 8 klon lainnya tidak berbeda dengan Cenning. Pembandingan dengan PS 881 diperoleh 6 klon $(87,104,212,354,451$, dan 400 SOF 1132) berjumlah ruas batang lebih banyak, dan 6 klon lainnya tidak berbeda. Semua klon yang diuji ditumbuhkan dalam lingkungan tumbuh yang homogen sehingga perbedaan jumlah ruas yang diperoleh disebabkan oleh perbedaan klon

Tabel 2. Kandungan khlorofil relatif dan hasil kuantum maksimal dari fotokimia primer (Fv/Fm) klon/ varietas tebu di lahan kering

\begin{tabular}{lcl}
\hline Klon/varietas & $\begin{array}{c}\text { Kandungan } \\
\text { khlorofil relatif }\end{array}$ & Fv/Fm \\
\hline 17 & $12.20 \mathrm{bc}$ & $0.710 \mathrm{a}-\mathrm{c}$ \\
87 & $12.18 \mathrm{bc}$ & $0.695 \mathrm{~b}-\mathrm{d}$ \\
90 & $10.38 \mathrm{de}$ & $0.670 \mathrm{c}-\mathrm{e}$ \\
104 & $14.62 \mathrm{a}$ & $0.728 \mathrm{ab}$ \\
212 & $12.31 \mathrm{bc}$ & $0.699 \mathrm{~b}-\mathrm{d}$ \\
351 & $9.18 \mathrm{f}$ & $0.646 \mathrm{de}$ \\
354 & $10.38 \mathrm{de}$ & $0.685 \mathrm{~b}-\mathrm{e}$ \\
451 & $9.57 \mathrm{ef}$ & $0.652 \mathrm{de}$ \\
452 & $8.31 \mathrm{~g}$ & $0.642 \mathrm{e}$ \\
PBG 2 & $10.49 \mathrm{~d}$ & $0.670 \mathrm{c}-\mathrm{e}$ \\
386 SOF 1118 & $14.93 \mathrm{a}$ & $0.754 \mathrm{a}$ \\
400 SOF 1132 & $10.24 \mathrm{de}$ & $0.648 \mathrm{de}$ \\
PS 881 & $11.58 \mathrm{c}$ & $0.664 \mathrm{c}-\mathrm{e}$ \\
Cenning & $11.43 \mathrm{c}$ & $0.676 \mathrm{~b}-\mathrm{e}$ \\
\hline
\end{tabular}

Keterangan: Angka yang didampingi minimal satu huruf sama dalam satu kolom berarti tidak berbeda nyata pada uji jarak ganda Duncan (DMRT) taraf 5\% yang digunakan. Naga-Madhuri et al. (2011) dan Viator et al. (2010) menyebutkan jumlah ruas batang tebu dipengaruhi oleh genetik tanaman.

Enam klon (212, 354, 451, 452, 386 SOF 1118, 400 SOF 1132) berpanjang ruas lebih pendek dan 6 klon lainnya tidak berbeda dengan Cenning. Pembandingan dengan PS 881 diperoleh 3 klon $(17,90$, dan PBG 2) berpanjang ruas lebih panjang, 3 klon (354, 451, dan 400 SOF 1132) lebih pendek, dan 6 klon lainnya tidak berbeda dengan PS 881 (Tabel 3). Panjang ruas batang tebu ditentukan oleh jumlah ruas dan karbohidrat yang tersedia untuk pertumbuhan batang. Karbohidrat yang tersedia untuk pertumbuhan batang ditentukan oleh laju fotosintesis tanaman yang dalam penelitian ini dicrminkan oleh peubah Fv/Fm. Analisis regresi linier berganda panjang ruas terhadap jumlah ruas dan Fv/Fm diperoleh nilai pengaruh (koefisien korelasi) sebesar $77.2 \%$ dengan jumlah ruas berkorelasi negatif dan Fv/Fm berkorelasi positif. Klon/varietas yang mempunyai jumlah ruas yang sedikit dan nilai Fv/Fm yang tinggi akan menghasilkan panjang ruas yang lebih panjang (Streck et al., 2010). Hasil penelitian Junejo et al. (2010), Patel et al. (2014) dan Gomathi et al. (2013) memperlihatkan perbedaan panjang ruas tebu akibat perbedaan varietas yang digunakan.

Empat klon (17, 87, 104, dan 212) berpanjang batang tidak berbeda dan 8 klon lainnya lebih pendek dibanding varietas Cenning. Pembandingan dengan varietas PS 881 diperoleh 1 klon (400 SOF 1132) berpanjang batang lebih pendek, 3 klon $(354,452$, dan 386 SOF 1118) yang tidak berbeda, dan 8 klon lainnya lebih panjang (Tabel 3). Panjang batang tersusun atas jumlah ruas dan panjang ruas batang. Analisis regresi linier berganda panjang batang terhadap jumlah dan panjang ruas diperoleh pengaruh gabungan sebesar 99.1\%. Klon/varietas yang mempunyai jumlah ruas batang yang lebih banyak dan panjang ruas yang lebih panjang akan menghasilkan panjang batang yang lebih panjang. Hasil penelitian Khan et al. (2012) memperlihatkan adanya korelasi positif antara panjang batang dengan panjang dan jumlah ruas batang. Streck et al. (2010) dan Islam et al. (2011) menyatakan perbedaan genetik tanaman tebu menyebabkan perbedaan panjang batang yang diperoleh.

Tiga klon $(17,87$, dan 354$)$ berdiameter batang lebih besar, dan 9 klon lainnya tidak berbeda dengan Cenning dan PS 881 (Tabel 3). Diameter batang ditentukan oleh panjang batang dan karbohidrat yang tersedia untuk pertumbuhan batang. Semakin pendek batang dan semakin besar karbohidrat yang tersedia untuk pertumbuhan batang maka semakin besar diameter batang yang diperoleh. Analisis regresi linier berganda diameter batang terhadap panjang batang dan $\mathrm{Fv} / \mathrm{Fm}$ menghasilkan nilai pengaruh sebesar $65.3 \%$ dengan panjang batang berpengaruh negatif dan Fv/Fm berpengaruh positif. Klon/varietas yang berpanjang batang lebih pendek dan bernilai Fv/Fm lebih tinggi akan menghasilkan diameter batang yang lebih besar. Hasil penelitian Streck et al. (2010) memperlihatkan adanya hubungan antara diameter batang dengan laju fotosintesis 
Djumali et al. / J. Agron. Indonesia 46(3):328-336

Tabel 3. Jumlah dan panjang ruas batang serta panjang dan diameter batang klon/varietas tebu di lahan kering

\begin{tabular}{lcccc}
\hline Klon/varietas & $\begin{array}{c}\text { Jumlah ruas } \\
\text { per batang }\end{array}$ & Panjang ruas $(\mathrm{cm})$ & $\begin{array}{c}\text { Panjang batang } \\
(\mathrm{cm})\end{array}$ & $\begin{array}{c}\text { Diameter batang } \\
(\mathrm{mm})\end{array}$ \\
\hline 17 & $15.6 \mathrm{fg}$ & $16.31 \mathrm{ab}$ & $253.65 \mathrm{~b}-\mathrm{e}$ & $30.33 \mathrm{a}-\mathrm{c}$ \\
87 & $17.0 \mathrm{c}-\mathrm{e}$ & $15.64 \mathrm{~b}-\mathrm{d}$ & $266.11 \mathrm{a}-\mathrm{c}$ & $31.81 \mathrm{a}$ \\
90 & $14.7 \mathrm{~g}$ & $16.97 \mathrm{a}$ & $249.62 \mathrm{c}-\mathrm{e}$ & $27.52 \mathrm{de}$ \\
104 & $18.1 \mathrm{bc}$ & $15.37 \mathrm{~b}-\mathrm{d}$ & $278.35 \mathrm{a}$ & $29.16 \mathrm{~b}-\mathrm{d}$ \\
212 & $17.6 \mathrm{~cd}$ & $15.11 \mathrm{~cd}$ & $264.37 \mathrm{a}-\mathrm{c}$ & $27.42 \mathrm{de}$ \\
351 & $16.0 \mathrm{e}-\mathrm{g}$ & $15.51 \mathrm{~b}-\mathrm{d}$ & $248.59 \mathrm{c}-\mathrm{e}$ & $23.76 \mathrm{f}$ \\
354 & $19.8 \mathrm{a}$ & $11.46 \mathrm{e}$ & $224.43 \mathrm{f}$ & $30.60 \mathrm{ab}$ \\
451 & $20.1 \mathrm{a}$ & $12.12 \mathrm{e}$ & $244.12 \mathrm{de}$ & $26.79 \mathrm{e}$ \\
452 & $16.4 \mathrm{~d}-\mathrm{f}$ & $14.65 \mathrm{~d}$ & $240.12 \mathrm{ef}$ & $26.28 \mathrm{e}$ \\
PBG 2 & $15.5 \mathrm{fg}$ & $16.03 \mathrm{a}-\mathrm{c}$ & $244.94 \mathrm{de}$ & $28.29 \mathrm{c}-\mathrm{e}$ \\
386 SOF 1118 & $16.0 \mathrm{e}-\mathrm{g}$ & $14.84 \mathrm{~cd}$ & $235.41 \mathrm{ef}$ & $29.51 \mathrm{~b}-\mathrm{d}$ \\
400 SOF 1132 & $17.3 \mathrm{c}-\mathrm{e}$ & $11.51 \mathrm{e}$ & $199.32 \mathrm{~g}$ & $26.72 \mathrm{e}$ \\
PS 881 & $15.4 \mathrm{fg}$ & $14.42 \mathrm{~d}$ & $221.01 \mathrm{f}$ & $27.89 \mathrm{de}$ \\
Cenning & $16.2 \mathrm{~d}-\mathrm{f}$ & $16.53 \mathrm{ab}$ & $268.38 \mathrm{ab}$ & $27.75 \mathrm{de}$ \\
\hline
\end{tabular}

Keterangan: Angka yang didampingi minimal satu huruf sama dalam satu kolom berarti tidak berbeda nyata pada uji jarak ganda Duncan (DMRT) taraf 5\%

dan panjang batang. Diameter batang tebu dipengaruhi oleh genetik tanaman dan lingkungan tumbuh (NagaMadhuri et al., 2011). Dalam kondisi lingkungan tumbuh yang homogen, diameter batang dipengaruhi oleh genetik tanaman (Menossi et al., 2008; Rahman et al., 2008).

Bobotbatang, jumlah batang terpanen dan produktivitas tebu berbeda antar klon yang digunakan (Tabel 4). Dua klon (104 dan 386 SOF 11182) mempunyai bobot batang lebih berat, 5 klon $(90,351,451,452$, dan 400 SOF 1132) lebih ringan, dan 5 klon lainnya tidak berbeda dengan Cenning. Pembandingan dengan PS 881 diperoleh 2 klon (351 dan 452) berbobot batang lebih ringan, 4 klon (90, 451, PBG 2, dan 400 SOF 1132) tidak berbeda dan 6 klon lainnya yang lebih berat. Bobot batang tersusun atas volume dan bobot jenis batang. Bobot jenis batang diasumsikan tidak berbeda sehingga bobot batang ditentukan oleh volume batang.

Tabel 4. Bobot dan batang terpanen serta produktivitas klon/varietas tebu di lahan kering

\begin{tabular}{lccc}
\hline Klon/varietas & $\begin{array}{c}\text { Bobot batang } \\
(\text { kg per batang) }\end{array}$ & $\begin{array}{c}\text { Jumlah batang } \\
\text { per m juring }\end{array}$ & $\begin{array}{c}\text { Produktivitas } \\
\left.(\text { ton ha })^{-1}\right)\end{array}$ \\
\hline 17 & $1.617 \mathrm{ab}$ & $8.8 \mathrm{fg}$ & $85.53 \mathrm{~b}$ \\
87 & $1.560 \mathrm{a}-\mathrm{c}$ & $8.3 \mathrm{~g}$ & $78.01 \mathrm{~b}-\mathrm{d}$ \\
90 & $1.338 \mathrm{de}$ & $9.2 \mathrm{ef}$ & $73.38 \mathrm{c}-\mathrm{e}$ \\
104 & $1.629 \mathrm{a}$ & $9.9 \mathrm{de}$ & $98.19 \mathrm{a}$ \\
212 & $1.617 \mathrm{ab}$ & $10.0 \mathrm{de}$ & $98.26 \mathrm{a}$ \\
351 & $1.198 \mathrm{f}$ & $11.8 \mathrm{~b}$ & $85.69 \mathrm{~b}$ \\
354 & $1.600 \mathrm{ab}$ & $6.9 \mathrm{~h}$ & $67.30 \mathrm{e}$ \\
451 & $1.213 \mathrm{ef}$ & $9.6 \mathrm{e}$ & $70.95 \mathrm{de}$ \\
452 & $1.000 \mathrm{~g}$ & $13.6 \mathrm{a}$ & $83.11 \mathrm{~b}$ \\
PBG 2 & $1.444 \mathrm{~cd}$ & $11.1 \mathrm{bc}$ & $97.42 \mathrm{a}$ \\
386 SOF 1118 & $1.647 \mathrm{a}$ & $8.1 \mathrm{~g}$ & $80.24 \mathrm{bc}$ \\
400 SOF 1132 & $1.247 \mathrm{ef}$ & $10.6 \mathrm{~cd}$ & $81.71 \mathrm{bc}$ \\
PS 881 & $1.358 \mathrm{de}$ & $9.1 \mathrm{ef}$ & $75.68 \mathrm{~cd}$ \\
Cenning & $1.481 \mathrm{bc}$ & $11.8 \mathrm{~b}$ & $105.42 \mathrm{a}$ \\
\hline
\end{tabular}

Keterangan: Angka yang didampingi minimal satu huruf sama dalam satu kolom berarti tidak berbeda nyata pada uji jarak ganda Duncan (DMRT) taraf 5\% 
Volume batang tersusun atas luas penampang dan panjang batang, dimana luas penampang batang dapat diwakili oleh diameter batang sehingga bobot batang dapat ditentukan oleh diameter dan panjang batang. Analisis regresi linier berganda bobot batang terhadap diameter dan panjang batang menghasilkan nilai pengaruh sebesar 79.3\%. Klon/varietas yang mempunyai diameter batang lebih besar dan panjang batang lebih panjang akan menghasilkan bobot batang yang lebih besar. Junejo et al. (2010) dan Shakoor-ruk et al. (2014) menyatakan bobot batang tebu ditentukan oleh diameter dan panjang batang. Jika panjang batang yang diperoleh tidak ada perbedaan maka bobot batang ditentukan oleh diameter batang dan demikian pula sebaliknya (Ghaffar et al., 2012). Hasil penelitian Chohan et al. (2014) memperlihatkan adanya perbedaan bobot batang yang dihasilkan akibat perbedaan klon/varietas tebu yang digunakan.

Satu klon (452) mempunyai jumlah batang terpanen lebih banyak, 2 klon (351 dan PBG 2) tidak berbeda, dan 9 klon lainnya yang lebih sedikit dibanding Cenning. Pembandingan dengan varietas PS 881 diperoleh 3 klon (87, 354 , dan 386 SOF 1118) mempunyai jumlah batang terpanen lebih sedikit, 4 klon (251, 452, PBG 2, dan 400 SOF 1132) yang lebih banyak, dan 5 klon lainnya tidak berbeda (Tabel 4). Jumlah batang tebu per satuan luas lahan dipengaruhi oleh genetik tanaman dan lingkungan tumbuhnya (Bashir et al., 2005). Dalam kondisi lingkungan tumbuh yang homogen, jumlah batang tebu ditentukan oleh genetik tanaman (NagaMadhuri et al., 2011). Hasil penelitian Dashora (2012) memperlihatkan perbedaan genetik tebu menghasilkan perbedaan jumlah batang tebu yang terpanen.

Tiga klon (104, 212, dan PBG 2) mempunyai produktivitas tidak berbeda dan 9 klon lainnya lebih rendah dibanding Cenning. Pembandingan dengan PS 881 diperoleh 1 klon (354) mempunyai produktivitas lebih rendah, 5 klon (87, 90, 451, 386 SOF 1118, dan 400 SOF 1132) tidak berbeda, dan 6 klon lainnya lebih tinggi (Tabel 4). Bobot batang dan jumlah batang terpanen merupakan komponen penyusun produktivitas tebu. Analisis regresi linier berganda produktivitas terhadap komponen penyusunnya menghasilkan nilai pengaruh sebesar $97.9 \%$. Klon/varietas yang memponyai bobot batang lebih besar dan jumlah batang terpanen lebih banyak akan menghasilkan produktivitas tebu yang lebih tinggi. Soomro et al. (2012) dan Tyagi et al. (2013) menyatakan produktivitas tebu ditentukan oleh bobot batang dan jumlah batang saat panen. Peningkatan jumlah batang tebu dan bobot batang menyebabkan peningkatan produktivitas tebu (Khalid et al., 2015; Djumali et al., 2017). Hasil penelitian Kumar et al. (2012) memperlihatkan perbedaan produktivitas tebu akibat perbedaan genetik tanaman yang digunakan.

Faktor perah, nilai nira dan potensi rendemen berbeda antar klon tebu yang digunakan (Tabel 5). Tiga klon (104, 212, dan 351) mempunyai faktor perah lebih besar, 2 klon (354 dan 451) lebih kecil, dan 7 klon lainnya tidak berbeda dengan Cenning. Pembandingan dengan varietas PS 881 diperoleh 4 klon $(104,212$, 351, dan PBG 2) mempunyai faktor perah yang tidak berbeda dan 8 klon lainnya yang lebih rendah. Faktor perah dipengaruhi oleh faktor genetik dan lingkungan tumbuhnya (Inoue et al., 2009). Dalam kondisi lingkungan tumbuh yang homogen, faktor perah dipengaruhi oleh genetik tanaman (Chohan et al., 2014). Kashif dan Khan (2007) menyatakan perbedaan genetik tanaman tebu menyebabkan perbedaan faktor perah yang diperoleh.

Klon 17 mempunyai nilai nira yang lebih rendah, tiga klon $(87,90$, dan 212) tidak berbeda, dan 8 klon lainnya lebih tinggi dibanding varietas Cenning. Pembandingan dengan varietas PS 881 diperoleh 5 klon (351, 354, 451, 386 SOF 1118, dan 400 SOF 1132) mempunyai nilai nira tidak berbeda dan 7 klon lainnya yang lebih rendah (Tabel 5). Nilai nira dipengaruhi oleh faktor genetik dan kondisi lingkungan tumbuh tanaman tebu (Singh et al., 2010). Dalam kondisi lingkungan yang homogen, nilai nira dipengaruhi oleh genetik tanaman (Chohan et al., 2014). Hasil penelitian Kashif dan Khan (2007) memperlihatkan perbedaan genetik tanaman menyebabkan perbedaan nilai nira.

Empat klon (17, 87, 90, dan 354) mempunyai potensi rendemen yang tidak berbeda dan 8 klon lainnya lebih tinggi dibanding varietas Cenning. Pembandingan dengan varietas PS 881 tidak diperoleh klon yang mempunyai potensi rendemen tidak berbeda maupun lebih tinggi (Tabel 5). Faktor perah dan nilai nira merupakan komponen penyusun potensi rendemen sehingga analisis regresi linier berganda potensi rendemen terhadap komponen penyusunnya diperoleh nilai pengaruh sebesar 99.6\%. Klon/varietas yang mempunyai faktor perah dan nilai nira lebih tinggi akan menghasilkan potensi rendemen yang lebih tinggi pula. Amolo et al. (2014) menyatakan potensi rendemen tebu ditentukan oleh faktor perah dan nilai nira. Bahrani et al. (2009) dan Keshavaiah et al. (2012) juga menyatakan peningkatan faktor perah dan nilai nira diikuti oleh peningkatan potensi rendemen yang dihasilkan. Hasil penelitian Kumar et al. (2012) memperlihatkan perbedaan rendemen tebu sebagai akibat perbedaan genetik tanaman.

Hasil hablur berbeda antar klon tebu yang digunakan (Tabel 6). Empat klon (104, 351, PBG 2, dan 400 SOF 1132) mempunyai hasil hablur lebih tinggi, 3 klon $(212,452$, dan 386 SOF 1111) yang tidak berbeda, dan 5 klon lainnya yang lebih rendah dibanding varietas Cenning. Pembandingan dengan varietas PS 881 diperoleh 6 klon (104, 212, 351, PBG 2, 386 SOF 1118, dan 400 SOF 1132) yang mempunyai hasil hablur tidak berbeda dan 6 klon lainnya yang lebih rendah. Produktivitas dan potensi rendemen merupakan komponen penyusun hasil hablur. Analisis regresi linier berganda hasil hablur terhadap komponen penyusunnya diperoleh nilai pengaruh sebesar $99.7 \%$. Klon/varietas yang mempunyai produktivitas dan rendemen yang tinggi akan menghasilkan hablur yang tinggi pula. Soomro et al. (2012 dan Rehman et al. (2014) menyatakan hasil hablur ditentukan oleh produktivitas tebu dan rendemen. Hasil penelitian Gomathi et al. (2013) memperlihatkan perbedaan hasil hablur sebagai akibat perbedaan genetik tanaman yang digunakan. 
Djumali et al. / J. Agron. Indonesia 46(3):328-336

Tabel 5. Faktor perah, nilai nira dan potensi rendemen klon/varietas tebu di lahan kering

\begin{tabular}{lllc}
\hline Klon/varietas & Faktor perah & Nilai nira & Potensi rendemen (\%) \\
\hline 17 & $0.537 \mathrm{e}$ & $11.34 \mathrm{e}$ & $6.08 \mathrm{e}$ \\
87 & $0.545 \mathrm{de}$ & $11.52 \mathrm{de}$ & $6.33 \mathrm{e}$ \\
90 & $0.534 \mathrm{e}$ & $11.67 \mathrm{de}$ & $6.25 \mathrm{e}$ \\
104 & $0.649 \mathrm{ab}$ & $14.45 \mathrm{c}$ & $9.43 \mathrm{~b}$ \\
212 & $0.662 \mathrm{a}$ & $12.62 \mathrm{~d}$ & $8.31 \mathrm{c}$ \\
351 & $0.621 \mathrm{a}-\mathrm{c}$ & $16.63 \mathrm{ab}$ & $10.17 \mathrm{~b}$ \\
354 & $0.469 \mathrm{f}$ & $16.69 \mathrm{ab}$ & $7.74 \mathrm{~cd}$ \\
451 & $0.458 \mathrm{f}$ & $17.68 \mathrm{a}$ & $8.00 \mathrm{c}$ \\
452 & $0.596 \mathrm{~b}-\mathrm{e}$ & $15.70 \mathrm{~b}$ & $9.39 \mathrm{~b}$ \\
PBG 2 & $0.605 \mathrm{a}-\mathrm{d}$ & $15.71 \mathrm{~b}$ & $9.46 \mathrm{~b}$ \\
386 SOF 1118 & $0.556 \mathrm{c}-\mathrm{e}$ & $17.86 \mathrm{a}$ & $9.91 \mathrm{~b}$ \\
400 SOF 1132 & $0.562 \mathrm{c}-\mathrm{e}$ & $17.67 \mathrm{a}$ & $9.85 \mathrm{~b}$ \\
PS 881 & $0.670 \mathrm{a}$ & $17.45 \mathrm{a}$ & $11.66 \mathrm{a}$ \\
Cenning & $0.544 \mathrm{de}$ & $12.57 \mathrm{~d}$ & $6.94 \mathrm{de}$ \\
\hline
\end{tabular}

Keterangan: Angka yang didampingi minimal satu huruf sama dalam satu kolom berarti tidak berbeda nyata pada uji jarak ganda Duncan (DMRT) taraf 5\%

Tabel 6. Hasil hablur klon/varietas tebu di lahan kering

\begin{tabular}{lc}
\hline Klon/varietas & Hablur $\left(\right.$ ton ha $\left.\mathrm{h}^{-1}\right)$ \\
\hline 17 & $5.16 \mathrm{ef}$ \\
87 & $4.95 \mathrm{f}$ \\
90 & $4.65 \mathrm{f}$ \\
104 & $9.24 \mathrm{a}$ \\
212 & $8.17 \mathrm{~b}-\mathrm{d}$ \\
351 & $8.69 \mathrm{ab}$ \\
354 & $5.32 \mathrm{ef}$ \\
451 & $5.69 \mathrm{e}$ \\
452 & $7.77 \mathrm{~cd}$ \\
PBG 2 & $9.16 \mathrm{a}$ \\
386 SOF 1118 & $7.97 \mathrm{~b}-\mathrm{d}$ \\
400 SOF 1132 & $8.24 \mathrm{bc}$ \\
PS 881 & $8.84 \mathrm{ab}$ \\
Cenning & $7.47 \mathrm{~d}$ \\
\hline
\end{tabular}

Keterangan: Angka yang didampingi minimal satu huruf sama dalam satu kolom berarti tidak berbeda nyata pada uji jarak ganda Duncan (DMRT) taraf 5\%

\section{KESIMPULAN}

Klon 104, 212, dan PBG 2 menghasilkan produktivitas tebu (97.42-98.26 ton $\mathrm{ha}^{-1}$ ) tidak berbeda dengan varietas Cenning (105.42 ton $\mathrm{ha}^{-1}$ ) tetapi lebih tinggi dibanding varietas PS 881 (75.68 ton $\mathrm{ha}^{-1}$ ). Potensi rendemen (9.439.46\%) klon 104 dan PBG 2 lebih besar dibanding Cenning (6.94\%) tetapi lebih kecil dibanding PS 881 (11.66\%), sedangkan hasil hablur (9.16-9.24 ton ha-1) lebih tinggi dibanding Cenning (7.47 ton $\mathrm{ha}^{-1}$ ) tetapi tidak berbeda dengan PS 881 (8.84 ton ha $\left.{ }^{-1}\right)$.

\section{UCAPAN TERIMA KASIH}

Penulis mengucapkan terima kasih kepada Kepala Balai Penelitian Tanaman Pemanis dan Serat yang telah membiayai penelitian ini melalui DIPA tahun 2017. Terima kasih ditujukan kepada Kepala Kebun Asembagus beserta staf dan semua pihak yang telah membantu dalam pelaksanaan kegiatan penelitian ini.

\section{DAFTAR PUSTAKA}

Amolo, R.A., D.O. Sigunga, P.O. Owuor. 2014. Evaluation of sugarcane cropping systems in relation to productivity at Kibos in Kenya. Inter. J. Agric. Policy Res. 2:256-266.

Anonymous. 2012a. CCM-200 plus operator's manual chlorophyll content meter. Opti-Sciences Inc.,USA.

Anonymous. 2012b. OS-30p+ chlorophyll fluorometer, field portable hand held instrument designed for $\mathrm{Fv} /$ Fm, Fv/F0 and advanced OJIP measurements. OptiSciences Inc.,USA.

Bahrani, M.J., M. Shomeili, S.H. Zande-Parsa, A. KamgarHaghighi. 2009. Sugarcane responsses to irrigation and nitrogen in subtropical Iran. Iran Agric. Res. 27:17-26. 
Bashir, S., A. Ali, M. Yasin. 2005. Sugarcane varieties and row spacing on sugarcane traits. Pakistan Sugar J. 20:18-20.

BPS. 2016. Statistik tebu Indonesia 2015. Badan Pusat Statistik. Jakarta.

Chohan, M., U.A. Talpur, S. JunejoO, G.S. Unar, R.N. Panhwar, B. Pa. 2014. Selection and evalution of the diverse sugarcane genotypes in $4^{\text {th }}$ stage. J. Anim. Plant Sci. 24:197-203.

Dashora, P. 2012. Productivity and sustainability of sugar (Saccharum officinarum) genotypes under planting seasons and fertility levels in south-east Rajasthan. Academia Arena. 4:37-41.

Ditjenbun, 2017. Statistik Perkebunan Indonesia 2015-2017 : Tebu. Direktorat Jendral Perkebunan, Jakarta.

Djumali, Lestari dan Supriyono. 2017. Penampilan tebu dari benih bagal dan budchip pada dua tata tanam di lahan kering. J. Agron. Indonesia 45:299-307.

Ghaffar, A., Ehsanullah, N. Akabr, S.H. Khan, K. Jabran, R.Q. Hashmi, A. Iqbal, M.A. Ali. 2012. Effect of trench spacing and micronutrients on growth and yield of sugarcane (Saccharum officinarum L.). Aust. J. Crop. Sci. 6:1-9.

Gomathi, R., P.N.G. Rao, D. Rakkyappan, B.P. Sundara, S. Shiyamala. 2013. Physiological studies on ratoonability of sugarcane varieties under tropical indian condition. American J. Plant Sci. 4:274-281.

Heliyanto, B., Djumali, E. Sugiyarta. 2016. Status of the development of high-yielding sugarcane varieties for rainfed areas in Indonesia. Proc. Int. Soc. Sugarcane Tech. 29:1674-1676.

Inoue, K., I. Yamane, T. Kaji. 2009. Effect of nitrogen topdressing and number off tillers at maximum tillering stage on the field and extract quality of ratoon sugarcane cultivar Ni 17. Japanese J. Soil Sci. Plant Nutr. 80:1-6.

Islam, M.S., M.A.S. Miah, M.K. Begum, M.R. Alam, M.S. Arefin. 2011. Growth, yield and juice quality of some selected sugarcane clones under water-logging stress condition. World J. Agric. Sci. 7:504-11.

Junejo, S., G.M. Kaloi, R.N. Panhwar, M. Chohan, A.A. Junejo, A.F. Soomro. 2010. Performance of newly developed sugarcane genotypes for some qualitative an quantitative traits under thatta conditions. J. Anim. Plant Sci. 20:40-43.
Kashif, M. and F.A. Khan. 2007. Disvergence in sugarcane (Saccharum officinarum L.,) based on yield and quality traits. Pak. J. Bot. 39:1559-1563.

Keshavaiah, K.V., Y.B. Palled, C. Shankariah, H.T. Channal, B.S. Nandihalli, K.S. Jagadeesha. 2012. Effect of nutrient management practices on nutrient dynamics and performance of sugarcane. Karnataka J. Agric. Sci. 25:187-192.

Khan, I.A., S. Bibi, S. Yasmin, A. Khatri, N. Seema, A.S. Abro. 2012. Correlletion studies of the agronomic traits for higher sur yield in sugarcane. Pak J. Bot. 44:969-971.

Khalid, S., F. Munsif, A. Ali, M. Ismail, N. Haq, S. Iqbal, M. Saeed. 2015. Evaluation of chipbud settling of sugarcane for enhancing yield to various row spacing. Inter. J. Agric. Envir. Res. 12:41-48.

Kumar, N., H. Singh, R. Kumar, V.P. Singh. 2012. Productivity and profitability of different genotypes of sugarcane (Saccharum spp) as influenced by fertility levels and planting seasons. Indian J. Agron. 57:180-185.

Menossi, M., M.G. Silva-Filho, M. Vincentz, M.A.VanSluys, G.M. Souza. 2008. Sugarcane functional genomics, gene discovery for agronomic trait development. Inter. J. Plant Gen. 2008: 1-11.

Naga-Madhuri, K.V., M.H. Kumar, N.V. Sarala. 2011. Influence of higher doses of nitrogen on yield and quality of early maturing sugarcane varieties. Sugar Tech. 13:96-98.

Patel, D., V.C. Raj, B. Tandel, B. Patel, D.U. Patel, V. Surve. 2014. Influence of planting distance and variety on growth of sugarcane and weed population under mechanization. J. Inter. Academic. Res. Multidisc. $2: 34-41$

Rahman, M.A., S.U.K. Eusufzai, S.S. Tabriz, S.M.I. Hossain. 2008. Optimization of irrigation level for selected sugarcane varieties in AEZ-11 of Bangladesh. The Agriculturists. 6:99-107.

Rehman, A., R. Qamar, J. Qamar. 2014. Economic assessment of sugarcane (Saccharum officinarum L.) through intercropping. J. Agric. Chem. Envir. 3:2428.

Shakoor-Ruk, A., M.N. Kandhro, S.K. Baloch, S. UllahBaloch, A. Bakhsh-Baloch. 2014. Impact of sett placement method and row directions on growth and yield of sugarcane variety LRK-2001. Persian Gulf Crop Protect. 3:53-59. 
Singh, N.P., R.D.N. Verma, R.G. Singh, S.B. Singh. 2010. Effect of planting geometry and nitrogen level on yield and juice quality of sugarcane. J. Sugar Tech. 2:40-43.

Soomro, A.F., S. Tunio, F.C. Oad, I. Rajper, M.I. Khuhro, M.Y. Arain. 2012. Effect of supplemental inorganic NPK and residual organic nutrients on sugarcane ratoon crop. Inter. J. Sci. Eng. Res. 3:1-11.

Stirbert, A., GY. Riznichenko, AB. Rubin, Govindjee. 2014. Modeling chlorophyll a fluorescence transient : relation to photosynthesis. Biochemistry (Moscow). 79:291-323.

Streck, N.A., J.G. Hanauer, L.F. Gabriel, T.C. Buske, J.A. Langner. 2010. Leaf development and growth of selected sugarcane clones in a subtropical environment. Pesq. Agropec. Bras. 45:1049-1057.
Tyagi, V.K., S. Sharma, S.B. Bhardwaj. 2013. Pattern of association among cane yield, sugar yield and their components in sugarcane (Saccharum officinarum L.). J. Agric. Res. 50:29-38.

Viator, R.P., C.D. Dalley, R.M. Johnson, E.P. Tichard. 2010. Early harvest affects sugarcane ratooning ability in Lousiana. Sugarcane Inter. 28:123-127.

Zhao, D., B. Glaz, M.S. Irey, C.J Hu. 2015. Sugarcane genotype variation in leaf photosynthesis properties and yield as affected by mill mud application. Agron. J. 107:506-514.

Zivcak, M., M. Brestic, K. Olsovska, P. Slamka. 2008. Performance index as a sensitive indicator of water stress in Triticum aestivum L. Plant Soil Environ. 54:133-139. 